\title{
YOUTH AS A KEY CATEGORY OF YOUTH WORK: CONCEPTUAL ASPECT
}

\author{
Natalia Levchenko ${ }^{1}$, Nataliia Kolyada ${ }^{2}$ \\ ${ }^{1}$ Candidate of Pedagogical Sciences, Associate Professor of Social Pedagogy and Social Work, Doctoral \\ Student, Pavlo Tychyna Uman State Pedagogical University, Uman, Ukraine, e-mail: \\ n.levchenkod@gmail.com,ORCID: https://orcid.org/0000-0002-5479-1907 \\ ${ }^{2}$ Doctor of Pedagogical Sciences, Professor Professor of the Department of Social Pedagogy and Social \\ Work, Pavlo Tychyna Uman State Pedagogical University, Uman, Ukraine, e-mail: koliada_n@ukr.net, \\ ORCID: https://orcid.org/0000-0003-3623-6552
}

Abstract. The article highlights various aspects of the definition of «youth», "youth work»; the main tasks of youth work are presented; analyzed a number of literary sources according to which it was determined that young people are the bearers of great intellectual potential, new and modern knowledge that they carry in all spheres of public life. In accordance with the purpose of the article - the analysis is carried out and the basic concepts of research «youth» and "youth work» are covered. The research used such methods as analysis, comparison and generalization of literature sources on the researched problem. International sources state that «young people are active participants in the life of society or organizations, partners with great potential, full of strength and talent; youth - the age category of the population of the state, which is directly aimed at by youth policy. The age range for young people in Ukraine is 14-35 years, in the Council of Europe and the European Union they are defined as 13-30 years old». In the period from 20152019, four studies of the values of modern youth in Ukraine were conducted and summarized in the following areas: youth values, effectiveness of youth policy (youth assessment); civic and political activity of youth; participation and role of youth in the processes of state reform; training, education; mobility and migration guidelines for young people; family and family values of young people. Theoretical analysis of various literary, normative, international sources states the fact that the concepts of "youth» and "youth work» as defined by all authors, scientists, politicians have something in common and all have their differences. Each of the above definitions has a right to exist. Youth is a socio-demographic group of society experiencing a period of social maturity, adaptation to the world of adults and future changes, which constantly replenishes politically and economically active population. people.

Keywords: youth, socio-demographic group, young people, youth work, work with young

JEL Classification: I 24, I 29

Formulas: 0; fig.: 0; tabl.: 0; bibl.: 26

Introduction. Economic, socio-political reforms have a significant impact on all spheres of social life of Ukraine. Youth as a socio-demographic group of the population needs a detailed analysis, identification and ways to solve the problems of their integration in society.

Different approaches of scientists to the study of modern inquiries of Ukrainian youth in the areas of implementation of state youth policy; issues of youth employment and involvement; educational plans of young people, their involvement in non-formal education; civic position and activity of youth; values and preferences of young people; involvement of young people in a healthy lifestyle; ways to spend free time and leisure of young people; the level of youth assessment of state youth policy; directions and forms of involving young people in the management of public affairs and community development; the influence of youth and the formation of civil 
society, reforming the economy, humanitarian sphere, European and Euro-Atlantic integration of Ukraine; the role of youth in the processes of state reform [14].

In Ukraine over the past decade, in order to analyze the social development of youth commissioned by the Ministry of Youth and Sports of Ukraine, sociological research is conducted, which examines the specifics of youth participation in social processes, its social and political activity, diagnoses existing needs and current problems.

In the period from 2015, four studies of the values of modern youth in Ukraine were conducted and summarized in the following areas: youth values, effectiveness of youth policy (youth assessment); civic and political activity of youth; participation and role of youth in the processes of state reform; training, education; mobility and migration guidelines for young people; family and family values of young people.

According to the results of four studies, young people determine the priorities of state youth policy - it is the support of talented youth $(2019-51.3 \%)$, the promotion of a healthy lifestyle $(2019-49.7 \%)$, promoting employment and self-employment of young people $(2019-35.6 \%)$, providing young people with housing (2019 $36.7 \%)$, development of youth infrastructure $(2019-26.7 \%)$ [1].

Also, according to the results of the study, the main needs of young people are identified: social and economic (financial needs, housing needs, education needs, employment needs, leisure needs, need for medical services); adherence to a healthy lifestyle; involvement in public life; national and patriotic identity; tolerance; assessment of the effectiveness of public policy.

The above facts confirm the importance of youth as a key category of youth work, which is aimed at the effectiveness of development and formation of youth.

Literature Review. In monographs, dissertations and other scientific works on the problems of social work, social pedagogy and sociology are largely covered: «Youth with disabilities and social media: public policy, project activities, inclusion» (L. Gulyaeva, J. Golovko, G. Phil, T. Semigina); «The concept and legal nature of youth unemployment» (A. Boyko); «Youth as a special socio-demographic group in the conditions of formation of the social-legal state and civil society» (B. Buyak), «Workshop on sociology of youth» (Y. Vyshnevsky, O. Kovaleva, V. Lukov, B. Ruchkin, V. Shapko); «Methodology and methods of studying the ideals of life plans of young people» (V. Lisovsky); «Sociology of Youth» (M. Golovaty); «Youth as an object of state policy» (M. Gutsalova); «Youth work: questions and answers» (I. Pesha, N. Tilikina, L. Mukoseeva); "Youth work at the local level in SouthEastern Ukraine: current status and prospects» (V. Ovcharova) and others $[2 ; 3 ; 4$; $12 ; 15 ; 16]$.

Aims. Is to carry out a theoretical analysis and cover basic concepts of the study «youth» and «youth work».

Methods. The research used such methods as analysis, comparison and generalization of literature sources on the researched problem.

Results. At the international level, the term youth was first introduced by the United Nations General Assembly in 1985, which sets the age range for a young person at 15-24 years. The World Health Organization later used the term «young 
people» to describe the age range from 10 to 24 years. In different countries and among different scientific trends there is a debatable age limit: the lower limit of youth is set by different authors between 14 and 16, and the upper - between 25 and 35 years.

During the period after implementation of the Law of Ukraine «On Promoting the Social Formation and Development of Youth in Ukraine» (1993) youth was defined as citizens of Ukraine aged from 15 to 28, and since 2004 - young people, young citizens - citizens of Ukraine aged 14 up to 35 years [20;22].

The widespread interest in the study of youth subcultures and the sociology of youth, the concepts of «youthfulness» and «youth» are considered in three aspects:

- as a certain biological age;

- as a certain condition due to socio-cultural criteria;

- as a certain group or generation with its inherent values.

Some scholars suggest the division of the age stage of youth into separate periods, based on the level of social maturity of young people, as well as their attitudes to various institutions of society: adolescents -11 (12) -14 years, juvenile15-17 (18) years, youth - 18-25 years old. In some scientific works we can find the division of a young person's life into three main periods: the first is the so-called search period, when a young person determines who to be, what to be, what profession, specialty to choose, where to realize their abilities; the second - the person is integrating into a society, labor activity of young men and girls in any sphere begins; third - the intensive creative work of the young person begins, his socialization and formation comes to an end [3].

A. Boyko, defines «youth» as a category of people aged from 14 to 35 who are at the initial stage of socialization, labor adaptation, endowed with legal labor personality and enjoy additional, compared to other employees, benefits and guarantees, including those in the field of employment [2].

In his work B. Buyak, considers youth as a special socio-demographic group in the conditions of formation of social and legal state and civil society and shares the opinion of I. Ilyinsky, that «youth is a history-specific concept, dependent on the nature and level of development of society. The world has never had, does not and will not have the concept of «youth» defined and accepted, once and for all» [3].

V. Lisovsky, defined youth «as a generation of people who go through the stage of socialization, assimilate, and in adulthood have already mastered educational, professional, cultural and other social functions, depending on specific historical conditions. He also believes that the age criteria for young people can range from 16 to 30 years» [12].

I. Kon, developed his own approach to the definition of «youth» and believes that «youth - is a socio-demographic group, distinguished on the basis of a set of age characteristics, social status and determined be these and other socio-psychological characteristics» [11].

In the work of B. Buyak, it is noted that «young people are the bearers of great intellectual potential, modern and new knowledge, which they carry in all spheres of public life. Youth is the most physically healthy part of the population, it is the life 
force of society, the conductor and accelerator of implementation of new ideas, initiatives, new forms of life» However, the basic definition of «youth» the author formulated in such wording «youth is a special socio-demographic group, transitional from children's lack of independence, incomplete responsibility for their actions, to adulthood - self-determination in sociality, economic independence» [2].

A. Boyko, believes that the age range of young people from 14 to 35 years is acceptable and justified due to the following circumstances: in recent decades, increased qualification requirements for employees, which provides for the extension of the training period; modern youth for socio-economic reasons in the years of professional development tests themselves in several areas of activity or after a certain period of work in the specialty moves to a related field [2].

According to the United Nations (UN), «adolescents are 10 to 19 years old and young people are 15 to 24 years old, which does not deprive member countries of the right to have other definitions. Adolescents and young people are collectively called «young people». Due to the limited data available in the report, this term can be applied to different age groups under the age of 34; Many surveys were conducted in compliance with the provisions of the legislation of Ukraine, according to which young people are people aged from 14 to 34 years [26].

The World Health Organization (WHO) estimates that young people are between the ages of 25 and 44 [19].

As M. Holovaty notes, «youth is a large socio-demographic group that occupies the state as the only source of replenishment of labor resources; youth - is the main carrier of the intellectual potential of society, which has great labor and creative abilities in all spheres of life; young people have enough social and professional development prospects (they are able to acquire new knowledge, professions and specialties faster than other social groups in society)» [6].

In the scientific research of K. Izmailova, it was determined that young people are a socio-demographic group, its population is determined by specific current socio-economic conditions of society. As a rule, the lower limit of age is from 14 years (during this period comes physical maturity and a citizen ready for work), the upper limit - the window depends on the acquisition of financial independence and professional stability [10].

In the Ukrainian academic dictionary: «Youth is a young, growing generation; juvenility» [25].

M. Gutsalova, defined the concept of «youth» as a socio-demographic group of society that is experiencing a period of social maturity, adaptation to the world of adults and future changes, which is constantly replenishing the politically and economically active population of the state. The author also notes that young people have moving boundaries of their age, which depends on the socio-economic development of society from the place it occupies in the social structure of society, the level of culture and living conditions, features of psychological development of a person [7].

O. Tsikhotska and L. Lozynska, believes that young people are a leading social group, because due to their objective state they concentrate and reveal in their minds 
the promising trends of modern society [16].

After analyzing international sources on the concept of «youth» can be identified as follows:

- «Youth - are active participants in society or organizations, partners with great potential, full of strength and talent»;

- «Youth - the age category of the population of the state, which is directly aimed by youth policy. The age range for young people in Ukraine is 14-35 years, in the Council of Europe and the European Union they are defined as 13-30 year olds» [24].

The Law of Ukraine «On Basic Principles of Youth Policy» (2021) stipulates that youth - young people - people aged from 14 to 35 who are citizens of Ukraine, foreigners and stateless persons who are in Ukraine legally [22].

In the terminological dictionary «Social Policy and Social Work» (2005) it is determined that «youth - a socio-demographic group, distinguished by a set of age characteristics, social status; citizens of Ukraine aged from 16 to 32 (abroad - up to 35)» [5].

After analyzing various sources on the concept of «youth», we note that a broad and detailed definition is given in the encyclopedia for social workers, the author of this concept - A. Gulevskaya-Chernysh, believes that youth - a differential social group that acquires the features of social community and has specific sociopsychological, social, cultural and other features, including lifestyle, is in the process of socialization, has its own social age and according to the needs of the time should be the creator or initiator of a new social and cultural reality» [9].

For the first time in Ukraine, a normative document has been adopted at the state level, which regulates youth work as an activity aimed at involving children and youth in public life carried out by children and youth, together with children and youth or in the interests of children and youth with the help of shared decisionmaking tools - the Law of Ukraine «On the basic principles of youth policy» (2021). The Law distinguishes the section "Youth Work», which reveals the content and main tasks of youth work. Youth work is focused on the needs of young people, aimed at acquiring the necessary competencies by young people, taking into account socio-economic conditions. Such work is carried out on the principles of voluntary participation of young people, accessibility, orientation of young people to intellectual, physical, spiritual development and provision of welfare [22].

Discussion. The concept of «youth work» is seen as working with a group of young people, managing a youth club, youth center, establishing contacts with various groups of young people on the street, mentoring, and so on. However, youth work is a partnership with young people [16]. According to N. Dzioba, L. Mukoseeva, N. Tilikina, O. Shkarupa youth work is «a holistic social phenomenon that unites all the subjects of social education and youth (family, immediate environment, educational institutions, peers) with the resources of traditional education and organized activities of youth work specialists» [16].

The main tasks of youth work in accordance with the Law include: development and satisfaction of various needs and interests of children and youth, promotion of 
their personal development and self-realization; formation of children's, youth's cultural, state and national values, educational and cognitive, civic, social, communicative, entrepreneurial and other competencies; development of volunteering, street cultures, informal youth associations, national and international exchange programs, youth tourism; implementation of programs of professional orientation, popularization and establishment of a healthy and safe way of life, culture of health; organization of meaningful leisure, cultural, emotional development of personality; providing partnership training for children and young people living in the temporarily occupied territory of Ukraine and internally displaced persons; introduction of an inclusive approach and ensuring equal access of every young person to qualities and opportunities of youth work [22].

Youth work is carried out by youth workers, youth and children's public associations, and other subjects of youth work.

According to the definition of the Council of Europe, youth work is a set of activities carried out with and for young people in the social, educational, cultural or political spheres. According to the Resolution on Youth Work of the Council of Europe, it is also generalized that youth work is based on non-formal and informal education, is conducted outside formal education, and is organized by youth forces and youth professionals. The main goals of youth work are integration and involvement of young people in society.

The content and goals of youth work and the age ranges of young people in different countries are different, namely: Norway (content: proposals for opportunities for leisure and individual development of youth through participation and social inclusion; goal: promotion of values of participation and democracy, social inclusion; group: less than 26 years); Estonia (content: creating conditions for the full development of the individual, which allows young people to act in good faith outside the family, education and work; purpose: creating the conditions and support for young people as members of society; age group: 7-26 years); Germany (content: creating opportunities to support the development and self-expression of young people in terms of their interests, social responsibility and involvement; goal: social and individual development based on the concepts of self-realization, participation and integration; age group: 14-27 years); The Netherlands (content: services that support young people; purpose: social inclusion and participation in public life; age group: less than 23 years); Ireland (content: managed educational process that supports individual and social development of youth through participation. Activities that complement formal education (mainly through non-governmental organizations); purpose: social and individual development of youth; age group: 10-25 years); Greece (content: education and leisure services that support the transition of young people to adult life; purpose: social and individual development of young people; age group: less than 30 years) [15].

Thus, young people are the main object of youth work, which promotes its development, helps to interact with the government and politicians, creates opportunities to participate in non-formal education, creates opportunities for healthy and meaningful leisure and recreation, etc. 
Youth work is key to all social, cultural, educational or political activities carried out with young people, for young people and by means of young people themselves [17].

Conclusion. After carrying out a theoretical analysis of various literary, normative, international sources, we can state the fact that the concept of «youth», «youth work» is defined by all authors, scientists, politicians in ways that are common and different. Each of the above definitions has a right to exist and we share them. However, we are more inclined to the definition of the concept of «youth» by M. Gutsalova that «youth - a socio-demographic group of society experiencing a period of social maturity, adaptation to the world of adults and future changes, which constantly replenishes politically and economically active population. At the same time it has moving boundaries of its age, which depends on the socio-economic development of society from the place it occupies in the social structure of society, the level of culture and living conditions, the peculiarities of psychological development». In our opinion, youth work is work with young people, which is aimed at: personal and professional development with the acquisition of relevant competencies; youth participation in public life (sport, leisure, youth employment, education and training, housing and transport, mobility and exchange, access to culture, health, sexual life, fight against violence and crime, gender equality, sustainable development, anti-discrimination, access to rights and the law); involving young people in planning and decision-making at the local, regional and national levels.

Prospects for further research in this direction are the theoretical aspect of training youth workers as implementers of youth policy.

Author contributions. The authors contributed equally.

Disclosure statement. The authors do not have any conflict of interest.

References:

1. Analitychnyi zvit z provedennia reprezentatyvnoho sotsiolohichnoho doslidzhennia stanovyshcha molodi $v$ Ukraini (2019 rik) [Analytical report on a representative sociological research of the situation of youth in Ukraine], Kyiv, 2019, $92 \mathrm{~s} . \quad$ URL: $\quad$ https://ukraine.un.org/sites/default/files/202006/THE\%20STATE\%20OF\%20YOUTH\%20IN\%20UKRAINE\%202019\%20\%D1\%83\%D0\%BA\%D1\%80. pdf [in Ukrainian].

2. Boiko, A. (2018), Poniattia ta pravova pryroda molodizhnoho bezrobittia [The concept and legal nature of youth unemployment], Pidpryiemnytstvo, hospodarstvo i pravo. Trudove pravo, Vyp. 2/2018, S. 69-73. URL: http://pgp-journal.kiev.ua/archive/2018/2/14.pdf [in Ukrainian].

3. Buiak, B. (2018), Molod yak osoblyva sotsialno-demohrafichna hrupa v umovakh stanovlennia sotsialnopravovoi derzhavy ta hromadianskoho suspilstva [Youth as a special socio-demographic group in the conditions of formation of the social-legal state and civil society], Naukovi zapysy, Vypusk 36, S. 198-209. URL: https://ipiend.gov.ua/wp-content/uploads/2018/07/buiak_molod.pdf [in Ukrainian].

4. Vishnevskiy, Yu. R., Kovaleva, A. I., Lukov, V. A., Ruchkin, B. A., Shapko, V. T. (2000), Praktikum po sotsiologii molodezhi [Workshop on sociology of youth], M., S. 24 [in Russian].

5. Holovatyi, M. F., Panasiuk, M. B. (2005), Sotsialna polityka i sotsialna robota : Terminol.-poniatiin.slov. [Social policy and social work: Term.-conceptual.dict.], K.: MAUP, S. 255 URL: https://maup.com.ua/assets/files/lib/book/nw53.pdf [in Ukrainian].

6. Holovatyi, M. F. (1999), Sotsyolohyia molodezhy: Kurs lektsyi [Sociology of youth: Course of lectures], K.: MAUP, S. 16-17. URL: https://subject.com.ua/pdf/99.pdf [in Ukrainian].

7. Hutsalova, M. (2011), Molod yak obiekt derzhavnoi polityky. Suchasna ukrainska polityka [Youth as an object of state policy. Modern Ukrainian politics], Polityky i politolohy pro nei. K., Vyp.22, S. 210-217. URL: http://dspace.nbuv.gov.ua/bitstream/handle/123456789/26850/23-Gutsalova.pdf?sequence=1 [in 
Ukrainian].

8. Elishev, S. O. (2017), Molodezhnaya problematika i podkhody $k$ opredeleniyu ponyatiya «molodezh» $v$ sotsiologii [Youth issues and approaches to defining the concept of «youth» in sociology], Vestn.mosk. unta. Ser.18. Sotsiologiya i politologiya, №3. URL: https://vestnik.socio.msu.ru [in Russian].

9. Entsyklopediia dlia fakhivtsiv sotsialnoi sfery [Encyclopedia for specialists in the social sphere], Za zah. red. Prof. I. D. Zvierievoi, Kyiv, Simferopol: Universum, 2012, S. 150 . URL: https://childfund.org.ua/Uploads/Files/books_pdf/ensyclopedia_social_work.pdf [in Ukrainian].

10.Izmaylova, K. A. (2018), Sotsiostrukturnaya kharakteristika rossiyskogo studenchestva: regionalnyy aspekt [Sociostructural characteristics of Russian students: regional aspect], dis. ... kand. sotsiol. nauk : 22.00.04 / Stavropol, 179 s. URL: https://www.ncfu.ru/export/uploads/doc/disser_ka_izmajlova.pdf [in Russian].

11. Kon, I. S. (1983), Molodezh [Youth], Filosofskiy entsiklopedicheskiy slovar. M., S. 384 [in Russian].

12. Lisovskiy, V. T. (1968), Metodologiya i metodika izucheniya idealov zhiznennykh planov molodezhi [Methodology and methods of studying the ideals of youth life plans.], Avtoref. kand. dis. L. URL: http://www.soc-mol.ru/encyclopaedia/researchers/95-lisovskiy.html [in Russian].

13. Molod Ukrainy - 2018. Rezultaty reprezentatyvnoho sotsiolohichnoho doslidzhennia [Youth of Ukraine - 2018. Results of a representative sociological research], Kyiv : DP «Redaktsiia informatsiinoho biuletenia «Ofitsiinyi visnyk Prezydenta Ukrainy», 2018, 72 s. [in Ukrainian].

14. Molod Ukrainy - 2015 [Youth of Ukraine - 2015.], Kyiv, 2015, 88 s. URL: https://sport.gov.ua/storage/app/sites/16/Mizhnarodna_dijalnist/Sociologichni_doslidzhennia/molod-ukraineblock.pdf [in Ukrainian].

15. Molodizhna polityka $v$ obiednanykh terytorialnykh hromadakh [Youth policy in united territorial communities], Posibnyk uchasnyka navchalnoho seminaru. Kyiv, 2018, 76 s. URL: Downloads/ManualYW$1 \% 20(1)$.pdf [in Ukrainian].

16. Molodizhna robota: zapytannia ta vidpovidi [Youth work: questions and answers], Navchalnometodychnyi posibnyk dlia fakhivtsiv, yaki pratsiuiut z moloddiu. Kyiv: DU «Derzhavnyi instytut simeinoi ta molodizhnoi polityky», 2020, 84 s. URL: https://dismp.gov.ua/molodizhna-robota-zapytannia-tavidpovidi/ [in Ukrainian].

17. Ovcharova,V. S. (2018), Molodizhna robota na lokalnomu rivni v Pivdenno-Skhidnii Ukraini: suchasnyi stan ta perspektyvy [Youth work at the local level in South-Eastern Ukraine: current status and prospects], Zaporizhzhia : vydavets FOP Mokshanov, V. V., $140 \mathrm{~s}$ URL: https://storage.decentralization.gov.ua/uploads/library/file/360/2018.pdf [in Ukrainian].

18. Osoblyvosti formuvannia tsinnisnykh oriientatsii studentskoi molodi v suchasnykh umovakh [Features of formation of value orientations of student's youth in modern conditions], Molod i rynok №1 (132), 2016, S. 39-43. URL: http://dspu.edu.ua/ddpu/biblioteka/chutach/fnv/molod_I_rynok/1_132_2016.pdf [in Ukrainian]. 19. Ofitsiinyi sait VOOZ [WHO official website]. URL: https://www.who.int/ru/news-room/feature-stories [in Ukrainian].

20. Pro vnesennia zmin do statti 1 Zakonu Ukrainy «Pro spryiannia sotsialnomu stanovlenniu ta rozvytku molodi v Ukraini» [On Amendments to Article 1 of the Law of Ukraine «On Promotion of Social Formation and Development of Youth in Ukraine»] vid 23.03.2004 r., № 1659-IV. URL: https://zakon.rada.gov.ua/laws/show/1659-15\#Text [in Ukrainian].

21. Pro osnovni zasady molodizhnoi polityky : Zakon Ukrainy [On the basic principles of youth policy: Law of Ukraine] vid 27.04.2021, № 1414-IKh. URL: https://zakon.rada.gov.ua/laws/show/1414-20\#Text [in Ukrainian].

22. Pro spryiannia sotsialnomu stanovlenniu ta rozvytku molodi v Ukraini : Zakon Ukrainy [On the promotion of social formation and development of youth in Ukraine: Law of Ukraine] vid 05.02.1993 r. № 2999-KhII (vtratyv chynnist vid 22.05.2021 r. № 1414-IKh) URL: https://zakon.rada.gov.ua/laws/show/2998-12\#Text [in Ukrainian].

23. Skazhy svoie slovo. Posibnyk z Perehlianutoi Yevropeiskoi khartii pro uchast molodykh liudei u mistsevomu ta rehionalnomu zhytti. Strasburh: Vydavnytstvo Rady Yevropy [Say your word. A handbook on the Revised European Charter on the Participation of Young People in Local and Regional Life. Strasbourg: Council of Europe Publishing House], 2015, 142 s. URL: https://rm.coe.int/have-your-say-manualukr/1680789a84 [in Ukrainian].

24. Slovnyk terminiv, yaki vykorystovuie Rada Yevropy u sferakh molodizhnoi polityky, prav liudyny ta neformalnoi osvity [Glossary of terms used by the Council of Europe in the fields of youth policy, human rights and non-formal education], $53 \mathrm{~s}$. https://sport.gov.ua/storage/app/sites/16/Mizhnarodna_dijalnist/Spivrobitnuctvo\%20z\%20radoy\%20EU/ukr- 
eng-dictionary-of-terminology-used-by-the-council-of-europe-in-the-youth-policy-field-for-human-rightsand-non-formal-education.pdf [in Ukrainian].

25. Slovnyk ukrainskoi movy: $v 11 \mathrm{tt}$. [Dictionary of the Ukrainian language: in $11 \mathrm{vols}$.], AN URSR. Instytut movoznavstva; za red. I. K. Bilodida. K.: Naukova dumka, 1970-1980, T. 4, S. 789 URL: http://ukrlit.org/slovnyk/\%D0\%BC\%D0\%BE\%D0\%BB\%D0\%BE\%D0\%B4\%D1\%8C [in Ukrainian].

26. Stanovyshche molodi v Ukraini [The state of youth in Ukraine], Analitychnyi zvit, skladenyi Robochoiu hrupoiu OON u spravakh molodi. Kyiv, 2019, 80 s. URL: https://ukraine.un.org/sites/default/files/202006/THE\%20STATE\%20OF\%20YOUTH\%20IN\%20UKRAINE\%202019\%20\%D1\%83\%D0\%BA\%D1\%80. pdf [in Ukrainian].

Received: August 21, 2021

Approved: September 23, 2021 